\title{
She is dead
}

Cite as: CMAJ 2021 November 8;193:E1704. doi: 10.1503/cmaj.211127

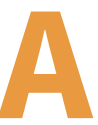

shrill flat line flutters on the heart monitor. She is dead. I stand slump shouldered, head bowed. My daughters wail.

A nurse rushes in. A chaplain and social worker follow. They want to cradle our loss. "Would you like to say a prayer?" "Can I get you anything?" "She's in a better place." Their words intrude. "No, I don't want a prayer." "No, there's nothing you can get." "No, she's not in a better place." A knock on the door. A medical intern enters. His coat is stained, his body rumpled. He smells of stale coffee. He is here to pronounce her dead, a legal necessity. He steps to the bed. He listens to her heart, one minute, maybe two. He searches for a pulse. His first death? He scribbles on the palm of his hand (time of death?), then clicks his pen. He clicks and clicks. Sweat gathers on his forehead. He glances at my wife. "Would you like an autopsy?" An autopsy, a cutting open of the body to determine cause of death. "No thank you." We know the cause; we want her home, home from a hospital in Los Angeles to a crematorium in Phoenix. The nurse approaches and grabs my arm, gently. "Spend as much time with her as you want." I want 30 more years.

We linger bedside. We touch her, we caress her, we kiss her. Her skin is cool, almost cold, the warmth already departed. I stand back and gaze at the room. It has become too small. "We should leave now." My daughters' eyes meet mine. I feel ashamed. How could I want to leave? I will never see her again. I tell them we will stay.

I step outside the room. I steady myself with a chair. The nurse approaches. "Have you made arrangements for the body?" The body. Not my wife, but the body. I have no arrangements. I did not think she would die, not this soon. The doctors said she would not die. They said she was coming home. They promised. Still, how could I have not known? Heart, lungs and kidneys failed. Defibrillator deactivated. How could I have not known? "I have no arrangements." I feel foolish, unprepared. The nurse motions to the social worker. She suggests a local funeral home. "They will arrange for your wife's remains to be returned home. She can be buried or cremated at that time." Her remains? Is that what she is now? Remains? "We'll call and make the arrangements. They'll need a credit card; you can give it to them when they arrive." Remains, credit card. Her death has become a business transaction.

I return to the room. My youngest daughter is unsettled. She is worried they will not treat her mother with respect in the morgue. I tell her yes, yes they will, but I do not know. Who does know? The undertaker arrives. He brings a solemn face and a smell of cologne. He speaks, but I do not hear. He places a pen in my hand. I sign paperwork I do not read; I mark the box labelled Widower. They will arrange a commercial flight home for her body. She will be with the luggage. In a coffin. A piece of coffin luggage. "We'll get 10 or 12 death certificates - you'll need them. It's easier to get them now rather than later." Get 10 or 12 ? Which is it, 10 or 12? Each time I look at one, she will die again. I do not want more than needed. "Spend as much time as you want with her. We'll pick her body up later this evening.
She'll fly home late tomorrow." I thank him; he hugs me tight. He leaves cologne on my clothes.

I close my eyes; I am lost and bewildered. I cannot think logically, my thoughts muddled and senescent. I go to the visitor's lavatory. I lock the door and rest my hands on the sink. I stare into the mirror. I turn my head side to side. My hair is dishevelled, my brow furrowed, my eyes red and surrendered. I cry and cry until I squeeze all the salt from my body, cleansing the pain, briefly. Then I cry again. A knock. My daughters; they are ready to leave. I open the door. The corridor glares fluorescent; I pinch my eyes narrow. I see the husband of a woman who is in the intensive care unit next to where my wife was. Was, as in past tense. He walks toward me. His lips move. "How is your wife?" I crumple against the wall. "She's dead." My daughters grab my arms. We walk to the elevator. I take one last breath of the air she breathed. The doors open and we descend. The world is no longer what it was. She is dead.

\section{Paul C. Rousseau MD}

Palliative care, Charleston, SC.

This article has been peer reviewed.

This is a true story.

Content licence: This is an Open Access article distributed in accordance with the terms of the Creative Commons Attribution (CC BY-NC-ND 4.0) licence, which permits use, distribution and reproduction in any medium, provided that the original publication is properly cited, the use is noncommercial (i.e., research or educational use), and no modifications or adaptations are made. See: https://creativecommons.org/ licenses/by-nc-nd/4.0/ 